\title{
Habitat exploitation by landbirds in the changing Western Samoan environment
}

\author{
S. M. EVANS, F. J. C. FLETCHER, P. J. LOADER and F. G. \\ ROOKSBY
}

\begin{abstract}
Summary
The avifauna of Western Samoa is dominated by indigenous species, including several endemic ones. They are primarily birds of the rainforest and, since the islands have already suffered severe loss of this habitat and there is likely to be increased pressure on it in the future, their long-term prospects are not good. At present, introduced, non-native birds are not a threat to indigenous species, being confined largely to urban habitats, and there is little interaction with forest species. Several indigenous species exploit manmodified habitats, however, and it is possible that, as has occurred elsewhere, some of them may adapt fully to urban life.
\end{abstract}

\section{Introduction}

Landbirds which inhabit small oceanic islands are highly vulnerable to extinction. Some island avifaunas, such as those of the Seychelles and Mascarenes in the Indian Ocean (Diamond 1985), and of Hawaii in the Pacific Ocean (Stone $1989 a, b)$, have suffered particularly badly, but the problem is widespread. According to King (1985), 93\% of the 93 species and 83 subspecies which became extinct between 1600 and 1800 were island forms. The introduction of alien predators to islands and the modification and loss of rainforests are almost certainly the main causes of species loss, but the establishment of populations of non-native bird species on islands, largely as a result of the survival of escaped or released cagebirds, deliberate attempts to introduce gamebirds, and efforts, particularly by European settlers, to "enrich" the environment with familiar species, may have contributed to the problem (Berger 1981).

Changes in island avifaunas have not, however, been recorded as they occurred, and there is a lack of information on, for example, the extent to which introduced species have invaded native forest habitats and, conversely, that to which indigenous species have become adapted to life in urban habitats. It is difficult, therefore, to predict the impacts of man's destruction of areas of rainforest on the birds of islands which still have rich avifaunas, and to recommend conservation measures to minimize them. The islands of Western Samoa are a case in point. There has already been serious loss of rainforests at low elevations, but those at higher levels have suffered less (Beichle and Maelzer 1985), and most of the islands' native birds still survive (Watling 1982). The avifauna consists of 35 species of landbird, with nine species or subspecies endemic to the islands (Watling 1982). The object of the present study was to investigate their use of habitats, particularly areas of natural rainforest and areas which have been modified by human interference. 


\section{Study sites and methods}

The studies were carried out from July to September 1989 . Sites were visited by observers (i.e. the authors) working in pairs or singly. They remained stationary during recording sessions, each of which lasted for approximately one hour, and recorded each separate bird sighting. The numbers of sightings in the natural forest are almost certainly underestimates because of the difficulties of making observations in such habitat. The sites, all of which were on the islands of Savaii and Upolu, were categorized into four broad habitat types as follows (numbers of replicate samples are shown in brackets after the number of hours surveyed): (1) natural forest: twenty-two sites, including areas of primary and secondary, lowland and upland, forest were surveyed for a total of 28.3 hours (28); (2) cleared forest (areas of forest where trees had been felled but the land was not under cultivation): twelve sites were surveyed for a total of 12.3 hours (12); (3) cultivated land: twenty-one areas of coconut plantation or farmland were surveyed for a total of 21.3 hours (21); (4) urban land: five sites, either in the town of Apia or in large villages, were surveyed for a total of 8.1 hours (8). The variation in the numbers of replicate samples for each of the habitat categories is a reflection of their relative extent and ease of access. The term "preferred habitat" (see below) is used to describe the habitat in which a species was sighted most frequently.

The nomenclature adopted is that used by Watling (1982). Although the study was limited to Western Samoa, the term "endemic" has been used to describe birds which are restricted in their distribution to the whole of the Samoan Islands (including Tutuila), since the group represents a more meaningful zoogeographic unit. Records were not kept of the occurrence of the Jungle Fowl Gallus gallus, which has been introduced to Western Samoa; it is probably impossible to separate feral populations from semi-feral or "wild" ones.

\section{Results}

The bird fauna of Western Samoa is rich in indigenous species. Of the total 27 landbirds recorded in this survey, 23 are indigenous, and six of them are endemic to Samoa (Table 1). Some additional indigenous species occur on these islands but were not recorded because they are rare (or probably extinct in the case of the Samoan Woodrail Pareudiastes pacificus: see Watling 1982) and/or because they are restricted to localized habitats which were not surveyed (e.g. the Samoan White-eye Zosterops samoensis). The four non-native species recorded were: Red-vented Bulbul Pycnonotus cafer, Jungle Myna Acridotheres fuscus, Common Myna A. tristis and feral pigeon Columba livia. Each is well established.

It is evident from Friedman Two-way Analyses of Variance that the number of sightings of birds within each of the three groups (introduced, endemic and indigenous $)$ is influenced by habitat type $\left(\chi_{\mathrm{r}}^{2}=60.9\right.$ for introduced species; 90.6 for endemic species; and 288.7 for indigenous species; $P<0.001$ in each case). There are different trends within the groups, however. Endemic and indigenous species dominated areas of forest, cleared forest and cultivated land, while introduced species were mostly confined to urban habitats. The preferred 
Table 1. Mean numbers of times ( \pm 1 standard deviation) that introduced, endemic and indigenous bird species were recorded per hour in each of four habitat categories.

\begin{tabular}{|c|c|c|c|c|}
\hline & \multicolumn{4}{|c|}{ Mean times species recorded per hour } \\
\hline & Forest & $\begin{array}{c}\text { Cleared } \\
\text { forest }\end{array}$ & $\begin{array}{l}\text { Cultivated } \\
\text { land }\end{array}$ & $\begin{array}{l}\text { Urban } \\
\text { land }\end{array}$ \\
\hline \multicolumn{5}{|l|}{ Introduced species: } \\
\hline Feral pigeon Columba livia & $0.1 \pm 0.5$ & $0.1 \pm 0.3$ & $0.2 \pm 0.4$ & $0.5 \pm 0.8$ \\
\hline Red-vented Bulbul Pycnonotus cafer & $0.1 \pm 0.3$ & $1.1 \pm 1.1$ & $0.7 \pm 1.0$ & $8.4 \pm 3.9$ \\
\hline Common Myna Acridotheres tristis & & & $0.1 \pm 0.3$ & $2.5 \pm 2.0$ \\
\hline Jungle Myna $A$. fuscus & & $0.4 \pm 0.4$ & $0.3 \pm 0.6$ & $2.0 \pm 1.5$ \\
\hline \multicolumn{5}{|l|}{ Indigenous species (endemic): } \\
\hline Flat-billed Kingfisher Halcyon recurvirostris & $0.4 \pm 0.7$ & $0.2 \pm 0.4$ & $0.7 \pm 1.2$ & $0.1 \pm 0.4$ \\
\hline Samoan Triller Lalage sharpei & $0.1 \pm 0.3$ & $1.0 \pm 1.7$ & & \\
\hline Samoan Fantail Rhipidura nebulosa & $1.4 \pm 1.8$ & $2.2 \pm 2.6$ & $0.4 \pm 0.6$ & $0.4 \pm 0.5$ \\
\hline Samoan Broadbill Myiagra albiventris & $0.1 \pm 0.4$ & $0.3 \pm 0.5$ & $0.2 \pm 0.5$ & \\
\hline Samoan Whistler Pachycephala flavifrons & $2.4 \pm 3.3$ & $0.2 \pm 0.6$ & $0.3 \pm 0.6$ & \\
\hline Samoan Starling Aplonis atrifusca & $7.5 \pm 5.6$ & $5 \cdot 7 \pm 5 \cdot 7$ & $5 \cdot 6 \pm 4 \cdot 7$ & $1.2 \pm 1.1$ \\
\hline \multicolumn{5}{|l|}{ Other indigenous species: } \\
\hline Banded Rail Gallirallus philippensis & $0.1 \pm 0.3$ & $0.9 \pm 1.1$ & $0.2 \pm 0.4$ & \\
\hline White-browed Crake Poliolimnas cinereus & & $0.2 \pm 0.4$ & & \\
\hline Purple Swamphen Porphyrio porphyrio & $0.1 \pm 0.3$ & & & \\
\hline White-throated Pigeon Columba vitiensis & $0.7 \pm 0.9$ & $0.3 \pm 0.9$ & $0.1 \pm 0.3$ & \\
\hline Friendly Ground-dove Gallicolumba stairii & & & $0.1 \pm 0.3$ & \\
\hline Pacific Pigeon Ducula pacifica & $0.2 \pm 0.4$ & & & \\
\hline Multi-coloured Fruit-dove Ptilinopus perousii & $0.1 \pm 0.3$ & & & \\
\hline Crimson-crowned Fruit-dove $P$. porphyraceus & $0.9 \pm 1.3$ & $0.2 \pm 0.4$ & $0.5 \pm 0.7$ & \\
\hline Blue-crowned Lory Vini australis & $1.6 \pm 1.8$ & $0.3 \pm 0.5$ & $2.8 \pm 3.4$ & $0.1 \pm 0.4$ \\
\hline Barn Owl Tyto alba & & & $0.1 \pm 0.3$ & \\
\hline White-rumped Swiftlet Collacalia spodiopygia & $4.5 \pm 2.9$ & $8.8 \pm 10.4$ & $8.0 \pm 8.2$ & $1.0 \pm 0.9$ \\
\hline Polynesian Triller Lalage maculosa & $5.1 \pm 4.9$ & $7 \cdot 5 \pm 4.1$ & $4 \cdot 4 \pm 2.8$ & $4.9 \pm 5.3$ \\
\hline Island Thrush Turdus poliocephalus & $0.3 \pm 0.5$ & $0.2 \pm 0.4$ & & \\
\hline Scarlet Robin Petroica multicolor & $0.5 \pm 0.7$ & $0.9 \pm 1.2$ & & \\
\hline Cardinal Honeyeater Myzomela cardinalis & $2.7 \pm 3.9$ & $5.0 \pm 2.8$ & $5.2 \pm 4.7$ & $3.0 \pm 1.9$ \\
\hline Wattled Honeyeater Foulehaio carunculata & $5.3 \pm 6.8$ & $4 \cdot 1 \pm 5 \cdot 7$ & $6.7 \pm 4.7$ & $0.6 \pm 0.7$ \\
\hline Red-headed Parrotfinch Erythrura cyaneovirens & $0.5 \pm 0.7$ & $1.5 \pm 1.6$ & & \\
\hline
\end{tabular}

habitat of each of the endemic $(n=6)$ and indigenous $(n=17)$ species was forest, cleared forest or cultivated land; that of each of the introduced species ( $n$ $=4$ ) was urban land (Table 2$)$. These differences are significant $(P<0.025$ for endemic vs. introduced species; $P<0.001$ for indigenous vs. introduced species; Fisher Exact Probability Test). Trends in the utilization of habitats are also reflected in the numbers of species recorded (and their relative densities) in them. Thus, the great majority of bird sightings in forest, cleared forest and cultivated land involved endemic and indigenous species (Table 2). This is due in part to the relatively large numbers of such species in these habitats, but also to the fact that those endemic and indigenous species which were recorded in them were sighted significantly more often than introduced species (Table 2). The difference was most evident in the forest itself, where several endemic and indigenous species were abundant but only two introduced birds were recorded, 
Table 2. Number of species, mean and percentage numbers of sightings, in each of the four habitat categories. Means are presented \pm one standard deviation. Statistical comparisons have been made of sightings of introduced species versus endemic ones, and introduced versus indigenous ones.

\begin{tabular}{|c|c|c|c|c|c|}
\hline & & Forest & $\begin{array}{l}\text { Cleared } \\
\text { forest }\end{array}$ & $\begin{array}{l}\text { Cultivated } \\
\text { land }\end{array}$ & $\begin{array}{l}\text { Urban } \\
\text { land }\end{array}$ \\
\hline \multirow{3}{*}{$\begin{array}{l}\text { Number of } \\
\text { species recorded }\end{array}$} & Introduced & 2 & 3 & 4 & 4 \\
\hline & Endemic & 6 & 6 & 5 & 3 \\
\hline & Indigenous & 14 & 12 & 10 & 5 \\
\hline \multirow{3}{*}{$\begin{array}{l}\text { Mean sightings } \\
\text { per hour }\end{array}$} & Introduced & $0.2 \pm 0.1$ & $1.6 \pm 0.9$ & $1.3 \pm 0.4$ & $13.4 \pm 9.6$ \\
\hline & Endemic & $11.9 \pm 4.6^{* * *}$ & $9.6 \pm 6.4^{*}$ & $7.2 \pm 2.9^{*}$ & $1.7 \pm 0.9^{* * *}$ \\
\hline & Indigenous & $22.6 \pm 7.3^{* * *}$ & $29.9 \pm 11.7^{* * *}$ & $28.1 \pm 13.1^{* * *}$ & $9.6 \pm 6.7$ \\
\hline \multirow{3}{*}{$\begin{array}{l}\text { Percent of total } \\
\text { sightings }\end{array}$} & Introduced & 0.6 & 3.9 & 3.6 & $54 \cdot 3$ \\
\hline & Endemic & 34.2 & $23 \cdot 4$ & 19.7 & 6.9 \\
\hline & Indigenous & 65.1 & 72.7 & 76.8 & 38.9 \\
\hline \multirow{3}{*}{$\begin{array}{l}\text { Mean sightings } \\
\text { per species recorded } \\
\text { per hour }\end{array}$} & Introduced & $0.1 \pm 0$ & $0.5 \pm 0.5$ & $0.3 \pm 0.3$ & $3.4 \pm 3.5$ \\
\hline & Endemic & $2.0 \pm 2.8^{* * *}$ & $1.6 \pm 2.2^{*}$ & $1.4 \pm 2.3^{*}$ & $0.6 \pm 0.6^{* *}$ \\
\hline & Indigenous & $1.6 \pm 2.0^{* * *}$ & $2.5 \pm 3.1^{* *}$ & $2.8 \pm 3.1^{* * *}$ & $1.9 \pm 2.0$ \\
\hline \multirow{3}{*}{$\begin{array}{l}\text { Percent sightings } \\
\text { per species recorded } \\
\text { per hour }\end{array}$} & Introduced & 2.7 & 10.0 & 6.7 & 57.6 \\
\hline & Endemic & 54.1 & 34.8 & 31.1 & 10.2 \\
\hline & Indigenous & 43.2 & $54 \cdot 3$ & 62.2 & 32.2 \\
\hline
\end{tabular}

${ }^{*} P<0.05 ;{ }^{* *} P<0.01 ;{ }^{* *} P<0.001$ (Mann Whitney U Test).

and then only infrequently. Introduced birds dominated urban habitats but some endemic and indigenous species, notably the Samoan Starling Aplonis atrifusca, Cardinal Honeyeater Myzomela cardinalis and Polynesian Triller Lalage maculosa, were also common in them.

Some endemic and indigenous species exploited feeding niches which have been created by man's interference with the environment, either in urban habitats or elsewhere on the islands. Thus, the Blue-crowned Lory Vini australis, Cardinal Honeyeater and Wattled Honeyeater Foulehaio carunculata foraged on the flowers of trees and shrubs in gardens and agricultural areas. The Flat-billed Kingfisher Halcyon recurvirostris, Samoan Starling, White-rumped Swiftlet Collocalia spodiopygia and Polynesian Triller fed on fruits and/or insects in such places. The Red-headed Parrotfinch Erythrura cyaneovirens exploited the highly modified vegetation along the edges of paths and roads through forests or areas of cleared forest. Non-native plants thrive in these places, and parrotfinches foraged in particular on the grasses Setaria glauca and Cynodon dactylon and the herbaceous plant Ageratum canyzoides. This bird species shows a remarkable range of feeding skills, since it was also seen foraging on the bark of the non-native tree Albizia chinensis, which occurs on some roadsides, and on the fruits of figs Ficus spp.

\section{Discussion}

The avifauna of Western Samoa is rich in endemic and indigenous species, and so far only five non-native species (including Jungle Fowl) have become 
established on the islands. The speed with which at least the three most recent colonizers have become established is, however, remarkable. The Red-vented Bulbul appears to have been introduced in 1943 (Watling 1978a), the Jungle Myna in 1970 (Watling 1978b) and the Common Myna not until 1988 (Beichle 1989). The high breeding success of colonizers of other urban environments, such as the American Goldfinch Carduelis tristis (Middleton 1979) and the Woodpigeon Columba palumbus (Tomiałojc 1976), has been attributed to reduced predation pressure and/or enhanced food supplies in towns. Similar factors probably account for the success of introduced species in establishing themselves so rapidly on Western Samoa.

There is no evidence that introduced species are in direct competition with native Samoan birds for resources such as food or breeding sites. Indeed, there is at present relatively little interaction between them. Introduced birds are confined primarily to urban areas. When they do encroach into the forest, it is probably only into regions where non-native food-plants have become established, as appears to be the case of the Red-vented Bulbul (see Watling 1978a). There is nevertheless a danger that introduced species will spread into the forest and that they will then compete with native species. The Jungle Myna and the Common Myna may be capable of doing so and, since both use hollows in trees as nest sites (Watling 1978b), they could compete with native holenesters, such as the Samoan Starling and the Blue-crowned Lory. There is also a danger that "new" introductions could be more successful in invading forests than the introduced species currently living in Samoa. The Japanese White-eye Zosterops japonicus has become established in rainforests on Hawaii (Berger 1981), as has the Silver-eye Z. lateralis on other Pacific islands (e.g. Thibault and Rives 1975). Either species could be a competitor with the Samoan White-eye, if it was introduced into Western Samoa.

There are, however, more immediate threats to the long-term survival of native Western Samoan birds. One of these is intensive hunting by local people using guns. Beichle and Maelzer (1985) suggested that the Tooth-billed Pigeon Didunculus strigirostris, the Crimson-crowned Fruit-dove Ptilinopus porphyraceus and the Multi-coloured Fruit-dove $P$. perousii were all endangered by this practice. There is a clear need therefore for school and community education programmes to encourage Samoan people to value and protect their wildlife. The major threat to Samoan birdlife is nevertheless loss of habitat owing to the destruction of rainforest for commercial, agricultural or urban development. As this study has shown, the endemic and indigenous species are primarily forest birds so that efforts of the Western Samoan government and other bodies to establish and maintain nature reserves (see e.g. Beichle and Maelzer 1985) are highly desirable.

Some endemic and indigenous species are, however, likely to survive habitat loss because they are able to adapt to environmental change. There is already evidence of this occurring on Western Samoa. Thus, the Polynesian Triller and the Cardinal Honeyeater have become common town birds. Nevertheless, full adaptation to the urban environment will depend on species satisfying the full range of their requirements in it, including those for breeding. The Red-headed Parrotfinch is one bird for which such adaptation may be possible, particularly since its close relative Peale's Parrotfinch Erythrura pealii has adapted success- 
fully to city and suburban life on Fiji (Watling 1982). The parrotfinches as a group have in fact proved highly adaptable, first in exploiting available niches (e.g. foods from forest plants) when they originally invaded Pacific Islands, and then in shifting niches as a result of competition with other species (Ziswiler et al. 1972, Diamond and Marshall 1977). Some of them have also adapted successfully to man-induced changes in the environment by reverting to the typical grass-seed-eating habit of other members of the family Estrildidae (Goodwin 1982). For example, Peale's Parrotfinch exploits introduced lawn grasses and rice on Fiji, the latter to such an extent that it has become a pest of rice-growers (Watling 1982). Similarly, the Pin-tailed Parrotfinch E. prasina exploits rice on Borneo and its populations also reach pest proportions (Evans and Fidler 1990). The Red-headed Parrotfinch already feeds on introduced grasses on Samoa and, since the abundance of this source of food will inevitably increase with further urbanization, it may emulate its relative $E$. pealii in adapting to man-modified environments.

\section{Acknowledgements}

The authors are most grateful to Autosmart Ltd., and especially the Managing Director, Mike Fidler, the University of Newcastle Exploration Society, the British Ecological Society, the Edmund Burtt Fund, the Sir James Knott Trust, the Sir John Priestman Charity Trust and the Australian Finch Society for financial help. We are also pleased to acknowledge help from Mr Tongi, Mr Mongeli, Dr M. Muckerhide, Dr S. Pearsall, Dr P. J. Jones, Dr S. Ericsson and Dr C. L. J. Frid.

\section{References}

Beichle, U. R. (1989) Common mynah on Upolu: first record for the Western Samoan islands. Elepaio 49: 85-86.

Beichle, U. and Maelzer, M. (1985) A conservation programme for Western Samoa. Pp.297-299 in A. W. Diamond and T. E. Lovejoy, eds. Conservation of tropical forest birds. Cambridge, U.K.: International Council for Bird Preservation (Techn. Publ. 4).

Berger, A. J. (1981) Hawaiian birdlife. Second edition. Honolulu: University of Hawaii Press.

Diamond, A. W. (1985) The conservation of landbirds on islands in the tropical Indian Ocean. Pp. 85-100 in P. J. Moors, ed. Conservation of island birds. Cambridge, U.K.: International Council for Bird Preservation (Techn. Publ. 3).

Diamond, J. M. and Marshall, A. G. (1977) Niche shifts in New Hebridean birds. Emu 77 : 61-72.

Evans, S. M. and Fidler, M. E. (1990) Parrot finches: the aviculturists' guide. London: Blandford.

Goodwin, D. (1982) Estrildid finches of the world. Oxford: British Museum (Natural History) and Oxford University Press.

King, W. B. (1985) Island birds: will the future repeat the past? Pp.3-15 in P. J. Moors, ed. Conservation of island birds. Cambridge, U.K.: International Council for Bird Preservation (Techn. Publ. 3).

Middleton, A. L. A. (1979) Influence of age and habitat on reproduction by the American Goldfinch. Ecology 60: 418-432.

Stone, C. P. (1989a) Non-native land vertebrates. Pp.88-95 in C. P. Stone and D. B. Stone, eds. Conservation biology in Hawaii. Honolulu: University of Hawaii Press. 
Stone, C. P. (1989b) Native birds. Pp.96-102 in C.P. Stone and D. B. Stone, eds. Conservation biology in Hawaii. Honolulu: University of Hawaii Press.

Thibault, J. C. and Rives, C. (1975) Birds of Tahiti. Papeete: Éditions du Pacifique.

Tomiałojc, L. (1976) The urban population of the Woodpigeon (Columba palumbus Linnaeus 1758) in Europe, its origin, increase and distribution. Acta Zool. Cracoviensis 21: 585-631.

Watling, D. (1978a) Observations on the naturalised distribution of the Red-vented Bulbul in the Pacific, with special reference to the Fiji Islands. Notornis 25: 109-117.

Watling, D. (1978b) A myna matter. Notornis 25: 117.

Watling, D. (1982) Birds of Fiji, Tonga and Samoa. Wellington: Millwood Press.

Ziswiler, V., Guttinger, H. R. and Bregulla, H. (1972) Monographie der Gattung Erythrura Swainson 1873 (Aves, Passeres, Estrildidae). Bonn. Zool. Monogr, no. 2.

\section{S. M. EVANS}

Dove Marine Laboratory, Cullercoats, Tyne and Wear, NE3o 4 PZ, U.K.

\section{F. J. C. FLETCHER}

Dove Marine Laboratory, Cullercoats, Tyne and Wear, NE30 4PZ, U.K.

\section{P. J. LOADER}

Dove Marine Laboratory, Cullercoats, Tyne and Wear NE3O ${ }_{4} P Z, U . K$.

\section{F. G. ROOKSBY}

Dove Marine Laboratory, Cullercoats, Tyne and Wear, NE30 4 PZ, U.K. 